\section{Rowcovers and Mulch Alter Seasonal Strawberry Carbon Metabolism}

\author{
Karen L.B. Gast and James E. Pollard \\ Plant Science Department, University of New Hampshire, Durham, \\ NH 03824
}

Additional index words. Fragaria $\times$ ananassa, floating rowcovers

Under the short days and low temperatures of autumn, short-day strawberry plants accumulate carbohydrates and initiate floral buds, but as temperatures decline, leaf function slows and floral initiation ceases (Austin et al., 1961; Moore and Hough, 1962). Higher temperatures and greater exposure to light in autumn and spring under synthetic rowcovers may enhance some temperature-limited developmental processes in strawberry (Gast, 1988). Plants overwintering under rowcovers had higher and earlier yields than noncovered controls (Pollard and Cundari, 1988).

Evidence on whether higher temperatures under rowcovers during autumn and spring alter carbohydrate metabolism might be found by examining carbohydrate levels in plants grown under rowcovers. The objective of this experiment was to determine if rowcover/ mulch treatments in autumn and spring affect carbohydrate partitioning in strawberry by analyzing total nonstructural carbohydrates (TNSC), glucose, and fructose levels.

Dormant crowns of 'Earliglow' strawberry were planted on 5 June 1986 in a raised bed system, $0.9 \mathrm{~m}$ between rows and $10 \mathrm{~cm}$ between plants. Two treatments, rowcovers applied in autumn with a short-term winter straw mulch removed 27 Mar. 1987 and a control of no rowcovers in autumn with a long-term winter straw mulch removed 24 Apr. 1987, were replicated six times. Treatment selection represented recommended commercial practices. Each replicate contained 11 sample plots of 10 plants. The rowcover, an extruded polypropylene-polyamide mesh $\left(20 \mathrm{~g} \cdot \mathrm{m}^{-1}\right.$; Agronet, CDK International, Marietta, Ga. ), was applied 12 Sept. 1986 and removed at flowering on 12 May 1987.

To determine TNSC and soluble sugars in leaves, roots, and crowns during autumn and spring, plants were removed from randomly assigned sample plots at 3-week intervals from 11 Sept. until 3 Dec. 1986 and from 27 Mar. until 27 May 1987. TNSC were determined according to Smith (1979). Soluble sugars were determined via modifications (Gast, 1988) of an ethanol extraction method (Ferguson et al., 1979) and of Pierce Chemical Co. gas-liquid chromatography preparation method \#18 (1986-87 Handbook and Gen-

Received for publication 22 May 1989. Scientific no. 1619 from the New Hampshire Agricultural Experiment Station. The cost of publishing this paper was defrayed in part by the payment of page charges. Under postal regulations, this pape therefore must be hereby marked advertisement solely to indicate this fact.

HortScience, Vol. 26(4), ApriL 1991 eral Catalog, Pierce Chemical Co., Rockford, Ill).

In autumn, no treatment differences were found for TNSC levels over the sampling period for any plant part. Significantly higher $(P<0.05)$ soluble sugars levels occurred in December in rowcovered leaves than in controls (data not shown). This finding does not support the hypothesis that plants under rowcovers in autumn store more carbohydrates than control plants, but does indicate rowcovered leaves sustained translocate metabolism longer.

In spring, rowcovered root TNSC levels were consistently greater in the spring, although this difference was significant only with the onset of rapid growth (Table 1). Rowcovered root carbohydrate reserves were either not used for spring growth or were replenished. Although no treatment main effect differences for crown TNSC levels were found over the spring sampling period, there was an important significant treatment $x$ sample data interaction. Rowcovered crowns had lower TNSC levels than controls on the first two spring sampling dates and higher levels on the last two dates. Earlier exposure to light and higher temperatures under the rowcovers may have resulted in the earlier use of crown carbohydrates to support earlier growth in the plants. By the last two sampling dates, photosynthates appeared to have been translocated into the rowcovered crowns.
This is not surprising, since leaf TNSC, fructose, and glucose levels were higher in rowcovered plants than controls (Table 1).

Rowcover effects on carbon metabolism were most apparent in spring. Leaves apparently became photosynthetically independent sooner, as seen in higher TNSC, glucose, and fructose levels under rowcovers. This effect, in turn, altered the typical spring plant source-sink relationships in the rowcover plants. Carbohydrate losses from normal sources for early spring growth and development, i.e., the roots and crowns, were prevented by the presence of an earlier functioning leaf surface. Plant carbohydrate levels may be one of the factors limiting the potential development of subsidiary floral buds into producing marketable fruit. This study shows that rowcovers appear to be affecting the carbohydrate pool in the plants, especially in spring.

\section{Literature Cited}

Austin, M.E., V.G. Shutak, and E.P. Christopher. 1961. Responses of Sparkle strawberry to inductive cycles. Proc. Amer. Soc. Hort. Sci. 77:372-375.

Ferguson, J.E., D.B. Dickson, and A.M. Rhodes. 1979. Analysis of endosperm sugars in a sweet corn inbred (Illinois 677a) which contains the sugary enhancer(se) gene and comparison of se with other corn genotypes. Plant Physiol. 63:416-420.

Gast, K.L.B. 1988. Rowcover modification of carbon and mineral nutrient partitioning in strawberry (Fragaria $\times$ ananassa, Duch. ). PhD Diss., Univ. of New Hampshire, Durham.

Moore, J.N. and L.F. Hough. 1962. Relationships between auxin levels, time of floral induction and vegetative growth of the strawberry. Proc. Amer. Soc. Hort. Sci. 81:255-264.

Pollard, J.E. and C.M. Cundari. 1988. Over-wintering strawberry plants under rowcovers increases fruit production. HortScience 23:332333

Smith, D. 1979. Removing and analyzing total nonstructural carbohydrates from plant tissue. Ext. Bul. R2107. Univ. of Wisconsin-Madison.

Table 1. Percent of dry mass for TNSC of roots, crowns, and leaves and percent of dry mass for leaf fructose and glucose for 'Earliglow' strawberry, Spring 1987.

\begin{tabular}{|c|c|c|c|c|c|}
\hline \multirow[b]{2}{*}{ Treatment } & \multicolumn{4}{|c|}{ Sampling date } & \multirow{2}{*}{$\begin{array}{l}\text { Analysis } \\
\text { over time }\end{array}$} \\
\hline & 27 Mar. & $15 \mathrm{Apr}$. & 6 May & 27 May & \\
\hline \multicolumn{6}{|c|}{ Roots $(\%)$} \\
\hline Rowcover & 6.75 & 6.35 & 5.70 & 7.42 & Treatment $(\mathrm{T})^{*}$ \\
\hline Control & 6.16 & 6.20 & 3.99 & 3.81 & Time $(\mathrm{T})^{*}$ \\
\hline Significance & NS & NS & NS & $* *$ & $\mathrm{~T} \times \mathrm{T}^{*}$ \\
\hline \multicolumn{6}{|c|}{ Crowns (\%) } \\
\hline Rowcover & 7.89 & 4.59 & 8.57 & 7.90 & Treatment $(\mathrm{T})^{\mathrm{NS}}$ \\
\hline Control & 9.26 & 7.25 & 5.21 & 4.94 & Time $(\mathrm{T})^{* * *}$ \\
\hline Significance & * & $* * *$ & $* *$ & $* *$ & $\mathrm{~T} \times \mathrm{T}^{* * *}$ \\
\hline \multicolumn{6}{|c|}{ Leaves (\%) } \\
\hline Rowcover & 7.19 & 9.28 & 11.28 & 13.28 & Treatment $(\mathrm{T})^{* * *}$ \\
\hline Control & 5.13 & 4.98 & 7.90 & 9.90 & Time $(\mathrm{T})^{* * *}$ \\
\hline Significance & $*$ & $* *$ & $* * *$ & $* *$ & $\mathrm{~T} \times \mathrm{T}^{\mathrm{NS}}$ \\
\hline \multicolumn{6}{|c|}{ Leaf fructose (\%) } \\
\hline Rowcover & 1.00 & 1.40 & 1.32 & 0.89 & Treatment $(\mathrm{T})^{* *}$ \\
\hline Control & 0.94 & 0.66 & 0.80 & 0.81 & Time $(\mathrm{T})^{\mathrm{NS}}$ \\
\hline Significance & NS & $* *$ & $*$ & * & $T \times T^{* *}$ \\
\hline \multicolumn{6}{|c|}{ Leaf glucose $(\%)$} \\
\hline Rowcover & 0.89 & 1.15 & 1.16 & 0.82 & Treatment $(\mathrm{T})^{\mathrm{NS}}$ \\
\hline Control & 0.82 & 0.53 & 0.65 & 0.65 & Time $(T)^{\mathrm{NS}}$ \\
\hline Significance & NS & $* *$ & $* *$ & $*$ & $\mathrm{~T} \times \mathrm{T}^{* *}$ \\
\hline
\end{tabular}

